\title{
Spatial Analysis of the Impact of Flood and Drought on Food Security Index
}

\author{
A. C. T. Rosalia $\uparrow$, Suryanto and L. Hakim \\ Department of Economics and Business, Sebelas Maret University, Surakarta 57127, Indonesia \\ $\dagger$ Corresponding author: A. C. T. Rosalia; ameliachoya@gmail.com
}

Nat. Env. \& Poll. Tech.

Website: www.neptjournal.com

Received: 02-06-2020

Revised: $06-07-2020$

Accepted: 16-07-2020

Key Words:

Flood

Drought

Food security index

\begin{abstract}
This research aims to spatially analyze the impacts of climate change, specifically flood and drought on the level of food security in the Bengawan Solo watershed. Agriculture is one of the sectors that is significantly affected by the phenomenon. Flood and drought disrupt agricultural productivity, resulting in farmers having difficulty accessing their livelihoods. This has the potential to threaten food security. This research was conducted in the Bengawan Solo watershed which flows through three provinces on the island of Java. Widespread watersheds and inadequate infrastructure make it difficult to monitor so that the areas through which rivers flow are vulnerable to flood and drought. The impact of these climate-related problems on food availability makes this research important. This research was started with the calculation of the food security index in each regency/city in the Bengawan Solo watershed regions and mapped it with a Geographic Information System (GIS). The step then proceeded to the impact assessment of flood and drought on food security using the quantitative method of panel data regression in the 2014-2018 period. To sum up, flood and drought contributed in a negative way to the level of food security. Information about food security is useful in planning the allocation of resources by the government. Therefore, efforts to strengthen food security can be more directed according to the needs.
\end{abstract}

\section{INTRODUCTION}

Climate change is happening more rapidly and is bringing an impact in various regions of Indonesia. From weather changes that endanger food production, to rising sea levels (United Nation 2019). Food security affected by climate change through increasing temperatures and extreme events (IPCC 2019). Climate variation will increase the risk of flood and drought. The connection between climate change and agricultural production is vigorous (Suryanto et al. 2020). Agricultural productivity is highly affected if there is any climate variation and it leads to food insecurity. Agricultural failure caused by nature and climatic conditions is quite high (Budhathoki et al. 2019). This has an impact on the quality of agricultural production and results in losses for farmers (Yang et al. 2010). So, it requires the development of calculations for farmers to address climate risks. Indonesia is an agricultural country whose population livelihood structure is dominated by the agricultural sector by $27.33 \%$ (Statistical Bureau of Indonesia 2019). Indonesia's Gross Domestic Product of $13.45 \%$ is occupied by the agricultural sector which is ranked the second largest after the industrial sector (Statistical Bureau of Indonesia 2019). This means that the survival of society depends on the agricultural sector. If agricultural productivity is disrupted, it will cause losses and increase poverty which also affects food security.
The agricultural product is prone to climate change (Deryugina \& Konar 2017). Climate change threatens food production systems that affect livelihoods and food security (Bhagawati et al. 2017). Referring to the data of the Centre for Research on the Epidemiology of Disaster (2018), Indonesia ranks 4 th in the world as the country experiencing the most natural disasters in 2018. The frequent occurrence of drought, water scarcity, and unsustainable intensive farming practices affect food security (Hameed et al. 2020). In a previous study in the Waduk Minyun watershed, it was found that watershed management had to be adjusted according to future climate change (Qiu et al. 2020). Community perceptions about floods and their impacts are extremely indispensable for Flood Risk Management exercises because they can increase the level of preparedness, response and recovery (Masud et al. 2018). Hunger and climate risk have a high correlation, particularly for areas most affected by food insecurity (Krishnamurthy et al. 2014). Food security is when everyone has sufficient, safe and nutritious food (Food Agricultural Organization 2006).

Flood and drought have proven agricultural failure, as happened in South Kulon Progo, Yogyakarta Province (Suryanto et al. 2020). The result of mapping areas prone to flood and drought using a Geographic Information System (GIS) was used to identify flood and drought effect on agricultural land (Saptutyningsih 2011). Sianturi et al. (2018) 
determined the crop pattern system in West Java Province which was applied in the form of mapping of the areas prone to flood vulnerability. Highly vulnerable areas have low productivity and high financing.

The purpose of this research is to investigate the impact of climate change, especially floods and drought in the Bengawan Solo watershed on the level of food security. The maps areas that are prone to flood, drought, and food insecurity showed by using geographic information systems that facilitate the identification of disaster-prone areas. Information about vulnerability to flood and drought in an area is highly significant in determining the treatment that will be provided by the government to prevent and overcome the risk of food vulnerability.

\section{MATERIALS AND METHODS}

The selected area for this research was the Bengawan Solo watershed. Watersheds are land areas that channel rainfall and snowmelt to tributaries, rivers, and streams, and eventually to exit points such as reservoirs, bays, and seas (National Oceanic and Atmospheric Administration 2020). Bengawan Solo is the largest river on Java island and drains water from a watershed of $\pm 16,100 \mathrm{~km}^{2}$ (Kementerian PUPR Ditjen Sumber Daya Air BBWS Bengawan Solo 2017). The research process was divided into 3 stages. First, mapping and ranking the scores of the food security index (FSI). Second, processing the data using panel data regression to determine the impact of flood and drought on food security in the Bengawan Solo watershed, and the last, processing the data of flood, drought, and food security using Geographic Information System (GIS).

Flood and drought are among the main challenges in watershed management systems. The frequency rising of rainfall can reduce the efficiency of management practices. River sedimentation also increases during climate change due to high rainfall (Qiu et al. 2020), this increases the potential for future floods and droughts. Flood risk prediction is useful for adaptation (Xu et al. 2019), as well as the risk of drought. Drought monitoring and assessment are important for mitigation and prediction (Okal et al. 2020). Spatial data analysis is needed to obtain information about potential floods, drought, and food security in the form of maps. Afterwards, the analysis of the effect of flood and drought on the level of food security can be performed. This research employed three analytical methods namely Food Security Index (FSI), geographic information systems, and panel data regression. Geographic Information System (GIS) in this study is to simulate food security levels based on food security index scores. Research on developing flood risk zone maps is very important and several research studies have been carried out on this issue worldwide (An et al. 2020)

Strategies to improve food security in each region are still constrained by the identification of the level of food security. Food Security Index (FSI) aims to show how to develop and validate potential indicators by comparing them with other indicators (Ibok et al. 2019). Spatial identification and scores of the food security index can help to both imaging and predicting, thus reducing losses. Meanwhile, panel data regression with Stata is a stated approach to find out the impact of flood and drought on the level of food security in the 5 years of 2014-2018.

There are several determining factors of food security, namely food accessibility, food availability, and food adequacy (Food Security Agency, 2018). The parameters used referred to the standard indicators by The Economist Intelligence Unit (2019) on the Global Food Security Index.

Table 1: Scores of expert judgement indicator.

\begin{tabular}{|c|c|c|c|}
\hline & \multirow[t]{2}{*}{ The Indicator Scores of Each Regency/City based on Expert Judgment } & \multicolumn{2}{|l|}{ Score } \\
\hline & & Regency & City \\
\hline \multicolumn{4}{|c|}{ Food Availability } \\
\hline 1 & The ratio of normative consumption to the net availability per capita per day & 0.30 & - \\
\hline \multicolumn{4}{|c|}{ Food Accessibility } \\
\hline 2 & The percentage of population below the poverty line & 0.15 & 0.20 \\
\hline 3 & The percentage of households with a proportion of expenditure on food is higher than $65 \%$ of total expenditure & 0.08 & 0.125 \\
\hline 4 & Percentage of households without access to electricity & 0.08 & 0.125 \\
\hline \multicolumn{4}{|c|}{ Food Utilization } \\
\hline 5 & The average years of schooling of women above 15 years & 0.05 & 0.08 \\
\hline 6 & Percentage of households without access to clean water & 0.15 & 0.18 \\
\hline 7 & The ratio of total population per health worker to population density & 0.05 & 0.08 \\
\hline 8 & Prevalence of stunting & 0.05 & 0.08 \\
\hline 9 & Life expectancy & 0.10 & 0.13 \\
\hline
\end{tabular}

Source: (Food Security Agency, 2018) 
The Food Security Index (FSI) is to evaluate achievements and classify food security. The three main steps of FSI calculation are as follows:

Step 1: Determination and ranking of the scores of the factors based on expert judgment: To calculate the index, each group of variables was scored based on the result of expert judgement from the Food Security Agency. The three aspects of food security, namely availability, accessibility, and utilization of food were investigated. Based on these three aspects, the results are provided in Table 1.

Step 2: Calculation of the food security index: Given that aspects of the food security index indicator have different units, it is necessary to do a normalization process in the calculation of the food security index. The normalization process in this research used the approach of $\mathrm{Z}$ max-min value and distance to scale (0-100). This was intended to make each data that had different units comparable. So that it could be used to generate conclusions. Following the maxmin, normalization was performed using the formula below:

$$
Z=\frac{X-X \min }{X \max -X \min }
$$

Where:

$\mathrm{X}=$ the score of each data

$\mathrm{Xmin}=$ the minimum score of $\mathrm{X}$

$\mathrm{Xmax}=$ the maximum score of $\mathrm{X}$

FSI score is the result of multiplication of each standardized indicator value with the score of the indicator (Food Security Agency, 2018), using the following formula:

$$
Y(j)=\sum_{n=1}^{9} a_{i} X_{i j}
$$

Where:

$\mathrm{Yj}=$ food security index of the $\mathrm{jth}$ regency or city

$\alpha i=$ score of each indicator city

$\mathrm{Xij}=$ standardized indicator score of the jth regency or

Step 3: Geographic Information System of a food security index: The Geographic Information System (GIS) application was used to analyze floods, droughts, and food security levels, then the results were displayed on maps.

Losses caused by climate change can reduce agricultural productivity. Farmers crop failure can be caused by flood and drought as happened in Kulon Progo (Saptutyningsih 2011) and the Yangtze River watershed (Liu et al. 2019). The variables used in this research were as follows:

$$
\begin{aligned}
& \text { FSI }=\alpha+\beta X_{1}+\beta_{2} X_{2}+\beta_{3} X_{3}+\beta_{4} X_{4}+\beta_{5} X_{5}+\beta_{6} X_{6} \\
& +\beta_{7} X_{7}+\mathrm{e} \\
& \text { Where, } \\
& \text { FSI = Food security index }=\text { Food security scores } \\
& \mathrm{X}_{1}=\text { Flood index } \quad=\text { Frequency of flood } \\
& \text { manifested in } \\
& \text { dummy variables }(0 \\
& \text { means no flood, and } \\
& 1 \text { means it experienc- } \\
& \text { es flood) } \\
& \mathrm{X}_{2} \quad=\text { Drought index } \\
& =\text { Frequency of drought } \\
& \text { manifested in dum- } \\
& \text { my variable (0 means } \\
& \text { no drought, and } 1 \\
& \text { means it experiences } \\
& \text { drought) } \\
& \mathrm{X}_{3} \quad=\text { Human develop- }=\text { The level of human } \\
& \text { ment index development } \\
& \mathrm{X}_{4}=\text { Inflation } \\
& \mathrm{X}_{5}=\text { Farm size } \\
& \mathrm{X}_{6}=\text { Total population } \\
& \mathrm{X}_{7}=\text { Gross Regional } \\
& \text { Domestic Product }
\end{aligned}
$$$$
\text { (GRDP) per capita }
$$

\section{RESULTS AND DISCUSSION}

The Bengawan Solo watershed stretches through three provinces namely Central Java, East Java and Yogyakarta Special Region. Areas in the present research consisted of three cities namely Surakarta, Madiun, Surabaya and 20 regencies which are Klaten, Boyolali, Wonogiri, Sukoharjo, Sragen, Karanganyar, Blora, Pacitan, Ponorogo, Rembang, Ngawi, Madiun, Magetan, Bojonegoro, Lamongan, Tuban, Gresik, Mojokerto, Trenggalek and Gunung Kidul. In this research, we used secondary data from the Central Statistics Agency (BPS), the National Disaster Management Agency (BNPB), and the Bengawan Solo River Region Centre. The Bengawan Solo watershed tends to have flood and drought vulnerability as shown in the maps provided in Fig. 1 and Fig. 2.

The Bengawan Solo watershed is an area that is vulnerable to flood and drought (Kementerian PUPR Ditjen Sumber Daya Air BBWS Bengawan Solo 2017). Therefore, it needs the role of various parties to prevent and minimize losses incurred. In Fig. 1, the GIS results show that almost the whole regencies/cities in the Bengawan Solo watershed 


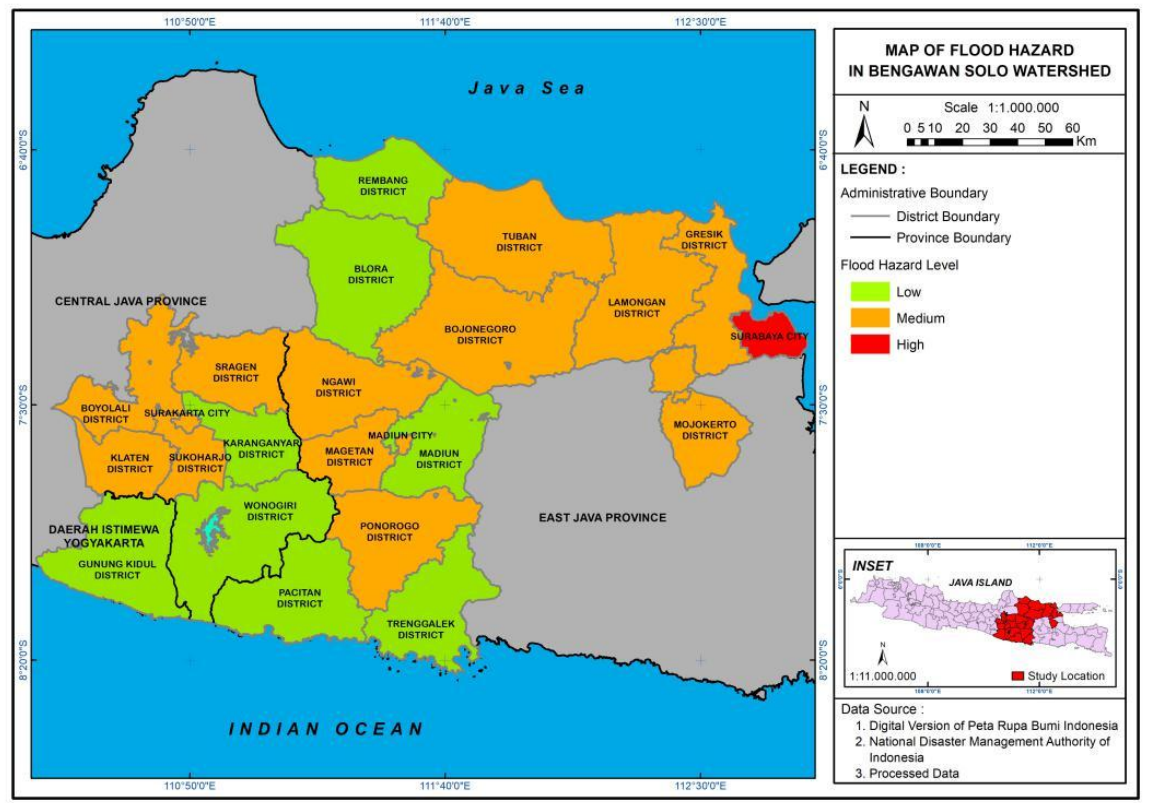

Fig. 1: Map of flood Risk in the Bengawan Solo Watershed.

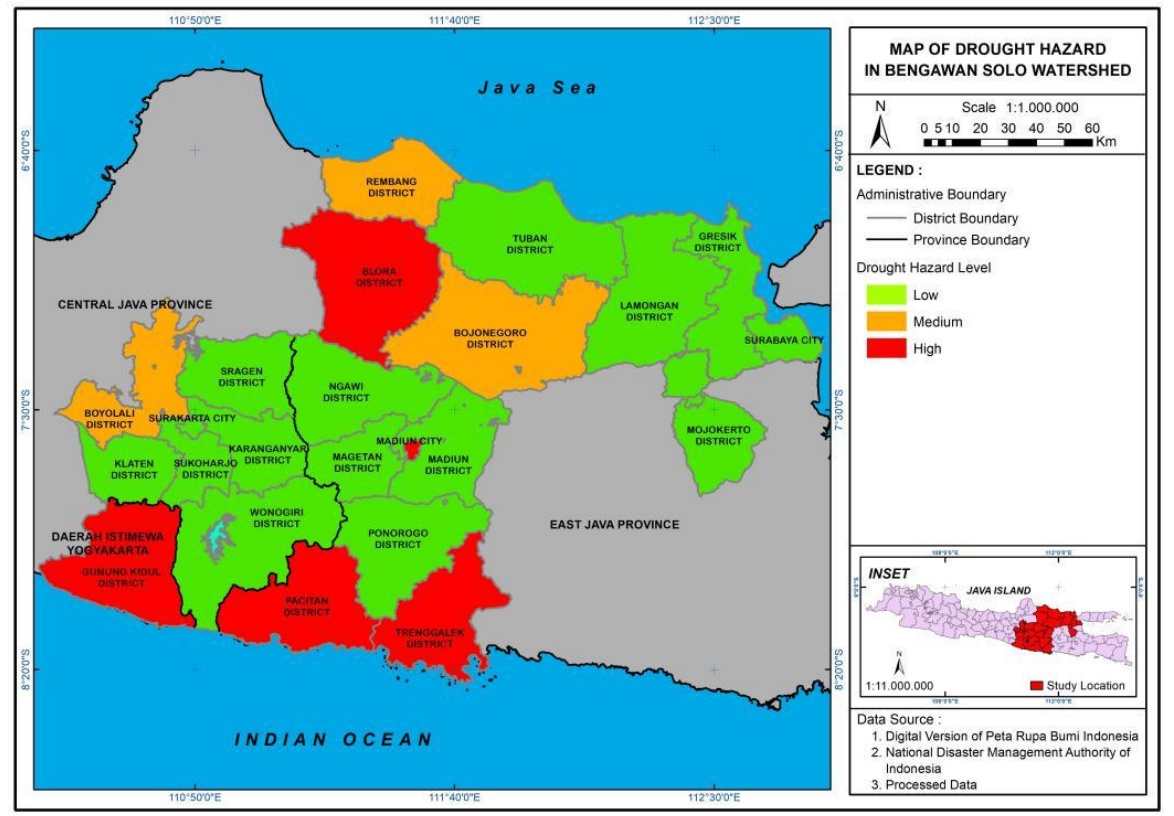

Fig. 2: Map of drought Risk in the Bengawan Solo Watershed.

have the potential to experience flood risk, but Surabaya has the highest risk of all. Some areas situated in Surakarta, Boyolali, Klaten, Sukoharjo, Sragen, Ngawi, Magetan, Ponorogo, Bojonegoro, Tuban, Lamongan, Gresik, and Mojokerto are also prone to flood at a moderate risk. Other areas have a low flood risk.
The drought risk areas are presented in Fig. 2. All the regencies/cities in the Bengawan Solo watershed have the potential to experience drought, but Gunung Kidul, Pacitan, Trenggalek, and Blora are considered as the regions with the highest risk. Some areas with moderate risks located in Boyolali, Rembang, and Bojonegoro. Drought occurs due 
Table 2: Food Security Index Score in Bengawan Solo Watershed.

\begin{tabular}{|lll|}
\hline No. & Regency/City & FSI Score 2014-2018 \\
\hline 1 & Surakarta & 67.43 \\
2 & Madiun & 70.32 \\
3 & Surabaya & 69.74 \\
4 & Boyolali & 63.8 \\
5 & Klaten & 63.4 \\
6 & Sukoharjo & 68.15 \\
7 & Wonogiri & 42.25 \\
8 & Karanganyar & 60.5 \\
9 & Sragen & 47.3 \\
10 & Blora & 40.9 \\
11 & Rembang & 58.75 \\
12 & Pacitan & 32.4 \\
13 & Ponorogo & 37.5 \\
14 & Madiun & 39.55 \\
15 & Magetan & 46.15 \\
16 & Ngawi & 23.8 \\
17 & Bojonegoro & 35.95 \\
18 & Tuban & 36.4 \\
19 & Lamongan & 41.05 \\
20 & Mojokerto & 61.3 \\
21 & Trenggalek & 39.45 \\
22 & Gresik & 32.95 \\
23 & Gunung Kidul & \\
\hline & & . \\
\hline
\end{tabular}

Source: Processed data, 2020 to minimal rainfall caused by climate change. While other areas have a low risk of drought.

It is necessary to measure regional food security scores to find out which regions have low food security (Table 2) so that the government can provide more intervention. The attempts to overcome food vulnerability can be well planned when it is visualized on a map. The region that has the highest FSI score is categorized as an area with good food security, on the contrary, the smallest FSI score indicates the regency/ city is vulnerable to food security.

Areas with a food security index map are presented in Fig. 3. All regencies/cities in the Bengawan Solo Watershed have the potential to experience food vulnerability risks. Based on the index score, the locations with the highest food security are Surabaya, Gresik, and Sukoharjo. This is due to the high level of GRDP per capita compared to other regions in the Bengawan Solo watershed. On the other hand, areas that have low food security/food insecurity are Gunung Kidul, Pacitan, and Ngawi. This is because these regencies/ cities have areas that tend to be vulnerable to floods and drought. Inadequate production of the agricultural sector has resulted in high levels of poverty in these regions. Other regencies/cities are categorized as regions with moderate levels of food security. The level of food security is influenced by several factors as described in the results of panel data regression (Stata) in the period of 2014-2018.

Table 3 presents panel data regression result of the variables that have the potential to affect the level of food security. Regression results show that flood and drought

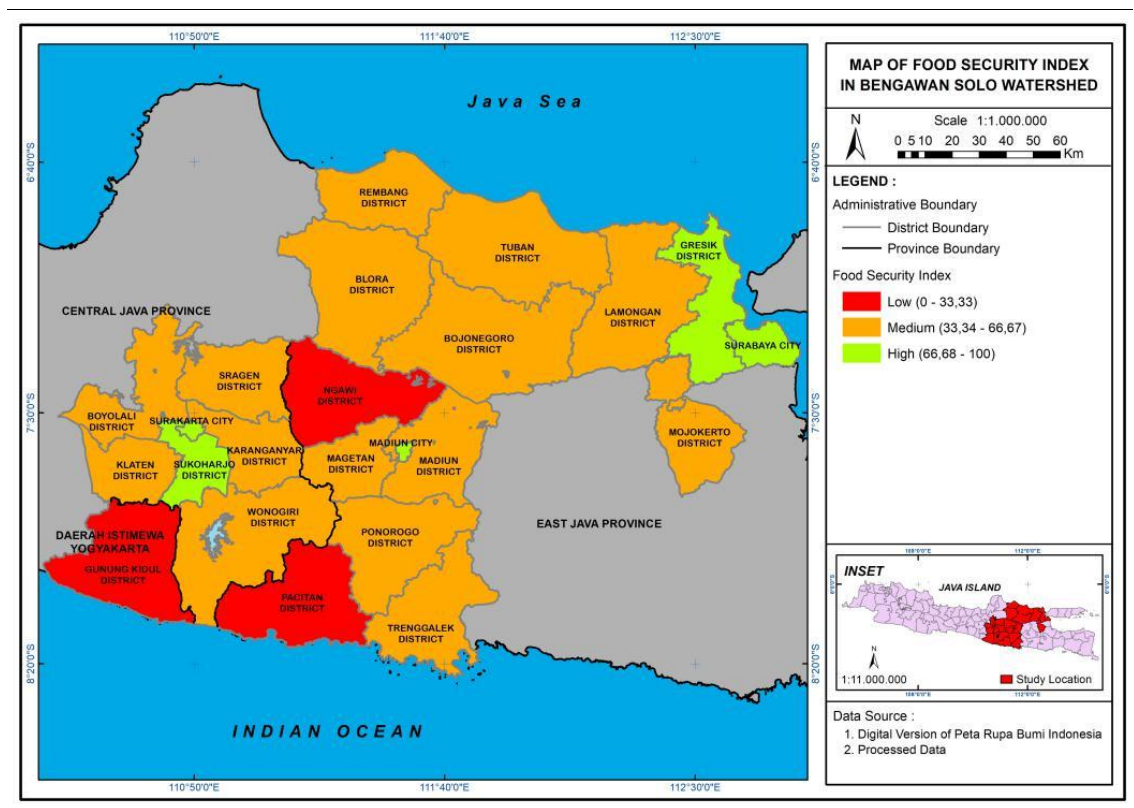

Fig. 3: Map of Food Security Index in the Bengawan Solo Watershed. 
Table 3: Variables contributing to the food security index.

\begin{tabular}{|llll|}
\hline Variable & Definition of variables & Coefficient & Probability \\
\hline IB & Dummy for flood & -4.809 & 0.034 \\
IK & Dummy for drought & -6.407 & 0.006 \\
IPM & Human development index & 2.902 & 0.000 \\
INF & Inflation & 0.232 & 0.409 \\
LLP & Farm size & 2.748 & 0.000 \\
JP & Total population & 1.317 & 0.493 \\
GRDP per capita & Gross regional domestic product per capita & 5.332 & 0.009 \\
cons & & 0.000 & \\
F (7.107) & & 31.48 & \\
Prob $>$ F & & 0.000 & \\
$\mathrm{R}^{2}$ & & 0.673 & \\
Adjusted $\mathrm{R}^{2}$ & & 0.651 & \\
Root MSE & & 9.089 & \\
Classic & & - & \\
Assumption & Heteroscedasticity & - & \\
\hline
\end{tabular}

Source: Processed Data, 2020

have a significant negative effect of $5 \%$ on the food security index, which means it reduces food security. In addition to flood and drought, other variables that influence the level of food security in the Bengawan Solo watershed are the human development index, farm size, and GRDP per capita which have a significant positive effect of $5 \%$, which means these variables increase food security.

Climate change, which causes flood and drought, is of concern to researchers because it will disrupt the supply of food availability. Areas that are identified as having low levels of food security must anticipate reducing the risk of potential losses. Food security in Indonesia is closely related to the price of rice (Timmer 2011) since it is the staple food of Indonesian. Indonesia is the 4th largest population in the world with a total of 264 million population based on (World Bank 2019). This causes the consumption of food to be relatively high. This research is expected to give support to the government in tackling the risk of food insecurity caused by climate change. By using GIS, areas that are prone to flood, drought, and food insecurity have been incorporated into the map so that it will ease the government in providing special treatment and intervention.

\section{CONCLUSION}

The contribution of climate change, especially floods and drought, to the level of food security in the Bengawan Solo watershed is crucial. Scores are grouped into three sectors of vulnerability in the Bengawan Solo watershed from the highest to lowest food security levels. From the results of the research, it can be concluded that flood and drought reduce the level of food security. That is, climate change causes additional burdens for the government to achieve development goals namely food security. Surabaya, Gresik and Sukoharjo are areas with high levels of food security. Whereas Gunung Kidul, Pacitan, and Ngawi are areas that have low food security or food vulnerability. Adaptation options for climate change and food distribution between regions can be alternatives. This research is expected to support the community and also the government so that it is easier to identify areas that need more attention to prevent food vulnerability in the rainy and dry seasons.

\section{ACKNOWLEDGMENT}

Thanks to the National Research and Innovation Agency of the Republic of Indonesia for part of the funding provided in this study.

\section{REFERENCES}

An, N. G. H. ¿, Nh, H. À. T. .., Thi, H., Huong, L. and Dzung, L. H. 2020. Flash flood risk zone map development for Thanh Hóa. Disaster Advances, 13(4): 40-51. Retrieved from https://worldresearchersassociations. com/disascurrissue/5.pdf

Bhagawati, R., Bhagawati, K., Jini, D., Alone, R. A., Singh, R., Chandra, A. and Shukla, K. K. 2017. Review on climate change and its impact on agriculture of Arunachal Pradesh in the Northeastern Himalayan region of India. Nature Environment and Pollution Technology, 16(2): 535-539.

Budhathoki, N. K., Lassa, J. A., Pun, S. and Zander, K. K. 2019. Farmers' interest and willingness-to-pay for index-based crop insurance in the lowlands of Nepal. Land Use Policy, 85(October 2018): 1-10. https:// doi.org/10.1016/j.landusepol.2019.03.029. 
Center for Research on the Epidemiology of Disaster 2018. Annual Disaster Statistical Review 2017. Retrieved from https://www.cred.be/

Deryugina, T. and Konar, M. 2017. Impacts of crop insurance on water withdrawals for irrigation. Advances in Water Resources, 110: 437444. https://doi.org/10.1016/j.advwatres.2017.03.013.

Food Agricultural Organization 2006. Food Security. Retrieved March 8, 2020, from http://www.fao.org/fileadmin/templates/faoitaly/ documents/pdf/pdf_Food_Security_Cocept_Note.pdf

Food Security Agency 2018. Indeks Ketahanan Pangan Indonesia 2018. Retrieved from http://bkp.pertanian.go.id

Hameed, M., Ahmadalipour, A. and Moradkhani, H. 2020. Drought and food security in the middle east: An analytical framework. Agricultural and Forest Meteorology, 281(October 2019): 107816. https://doi. org/10.1016/j.agrformet.2019.107816.

Ibok, O. W., Osbahr, H. and Srinivasan, C. 2019. Advancing a new index for measuring household vulnerability to food insecurity. Food Policy, 84(February): 10-20. https://doi.org/10.1016/j.foodpol.2019.01.011

IPCC 2019. Food Security. In Amfiteatru Economic (No. IPCC; Vol. 21). https://doi.org/10.24818/EA/2019/51/281

Kementerian PUPR Ditjen Sumber Daya Air BBWS Bengawan Solo. 2017. Sejarah Singkat. Retrieved March 20, 2020, from http://sda.pu.go.id/ bbwsbengawansolo/portal/index.php/sejarah-singkat/

Krishnamurthy, P. K., Lewis, K. and Choularton, R. J. 2014. A methodological framework for rapidly assessing the impacts of climate risk on national-level food security through a vulnerability index. Global Environmental Change, 25(1): 121-132. https://doi.org/10.1016/j. gloenvcha.2013.11.004

Liu, Y., You, M., Zhu, J., Wang, F. and Ran, R. 2019. Integrated risk assessment for agricultural drought and flood disasters based on entropy information diffusion theory in the middle and lower reaches of the Yangtze River, China. International Journal of Disaster Risk Reduction, 38(May): 101194. https://doi.org/10.1016/j.ijdrr.2019.101194.

Masud, M. M., Sackor, A. S., Ferdous Alam, A. S. A., Al-Amin, A. Q. and Abdul Ghani, A. B. 2018. Community responses to flood risk management - An empirical Investigation of the Marine Protected Areas (MPAs) in Malaysia. Marine Policy, 97(September): 119-126. https://doi.org/10.1016/j.marpol.2018.08.027.
National Oceanic and Atmospheric Administration 2020. What is a watershed? Retrieved April 29, 2020, from https://oceanservice.noaa. gov/facts/watershed.html

Okal, H., Ngetich, F. and Okeyo, J. 2020. Spatio-temporal characterisation of droughts using selected indices in Upper Tana River Watershed, Kenya. Scientific African, 7: e00275. https://doi.org/10.1016/j. sciaf.2020.e00275.

Qiu, J., Shen, Z., Hou, X., Xie, H. and Leng, G. 2020. Evaluating the performance of conservation practices under climate change scenarios in the Miyun Reservoir Watershed, China. Ecological Engineering, 143(July 2019), 105700. https://doi.org/10.1016/j. ecoleng.2019.105700.

Saptutyningsih, E. S. S. 2011. Hedonic Price Approach of Flood Effect on Agricultural Land. Economic Journal of Emerging Markets, 3(1): 87-96.

Sianturi, R., Jetten, V. G. and Sartohadi, J. 2018. Mapping cropping patterns in irrigated rice fields in West Java: Towards mapping vulnerability to flooding using time-series MODIS imageries. International Journal of Applied Earth Observation and Geoinformation, 66(November 2017): 1-13. https://doi.org/10.1016/j.jag.2017.10.013.

Statistical Bureau of Indonesia 2019. Indonesia Dalam Angka. Retrieved from https://www.bps.go.id/

Suryanto, N. A., Gravitiani, E., Daerobi, A. and Susilowati, F. 2020. Crop insurance as farmers adaptation for climate change risk on agriculture in Surakarta residency-Indonesia. International Journal of Trade and Global Markets, 13(2): 251. https://doi.org/10.1504/ijtgm.2020.106771.

The Economist Intelligence Unit 2019. Global Food Security Index. Retrieved from https://foodsecurityindex.eiu.com/

United Nation 2019. Climate Change. Retrieved from https://www.un.org/ en/sections/issues-depth/climate-change/

Xu, X., Wang, Y. C., Kalcic, M., Muenich, R. L., Yang, Y. C. E. and Scavia, D. 2019. Evaluating the impact of climate change on fluvial flood risk in a mixed-use watershed. Environmental Modelling and Software, 122, 104031. https://doi.org/10.1016/j.envsoft.2017.07.013.

Yang, R., Wang, L. and Xian, Z. 2010. Evaluation on the efficiency of crop insurance in China's Major Grain-Producing Area. Agriculture and Agricultural Science Procedia, 1: 90-99. https://doi.org/10.1016/j. aaspro.2010.09.011. 